\title{
WELCOMING AND BONDING IN THE CONCEPTIONS AND PRACTICES OF COMMUNITY HEALTH WORKERS
}

\author{
Rafaela De Carli ${ }^{1}$, Marta Cocco da Costaํ․ Ethel Bastos da Silva, Darielli Gindri Resta ${ }^{4}$, Isabel Cristina dos \\ Santos Colomé
}

\footnotetext{
${ }^{1}$ Nurse, Family Health Strategy in Seberi. Seberi, Rio Grande do Sul, Brazil. E-mail: rafaeladcarli@hotmail.com

2 Ph.D. in Nursing. Adjunct Professor, Health Sciences Department, Universidade Federal de Santa Maria (UFSM). Palmeira das Missões, Rio Grande do Sul, Brazil. E-mail: marta.c.c@ufsm.br

${ }^{3}$ Ph.D. in Nursing. Assistant Professor, Health Sciences Department, UFSM. Santa Maria, Rio Grande do Sul, Brazil. E-mail: ethelbastos@hotmail.com

${ }^{4}$ Ph.D. in Nursing. Adjunct Professor, Health Sciences Department, UFSM. Santa Maria, Rio Grande do Sul, Brazil. E-mail: darielli2004@yahoo.com.br

${ }^{5}$ Ph.D. in Nursing. Adjunct Professor, Health Sciences Department, UFSM. Santa Maria, Rio Grande do Sul, Brazil. E-mail: enfbel@yahoo.com.br
}

\begin{abstract}
Light technologies in health approximate professionals and users and serve as important tools in the work of Community Health Agents to know the families' difficulties and develop strategies. In this study, the aim was to get to know the concepts of welcoming and bonding of Community Health Agents in a city in the Northwest of Rio Grande do Sul and their use in care actions. This qualitative study involved 11 participants. Semistructured interviews were chosen for the data collection and thematic content analysis for data analysis. The study revealed welcoming as receptive acts and words and bonding as a relation of friendship, trust and commitment. These technologies were mainly used during home visits, when they exercise active listening and provide orientations. The need to equip the Community Health Agents and the health team is evidenced with a view to enhancing the understanding of the light technologies and acknowledging their relevance in health care.
\end{abstract}

DESCRIPTORS: Family health. Community health workers. User embracement.

\section{ACOLHIMENTO E VÍNCULO NAS CONCEPÇÕES E PRÁTICAS DOS AGENTES COMUNITÁRIOS DE SAÚDE}

RESUMO: As tecnologias leves em saúde aproximam profissional/usuário e constituem-se importantes ferramentas no trabalho dos Agentes Comunitários de Saúde para conhecer as dificuldades das famílias e elaborar estratégias. Neste estudo buscou-se conhecer as concepções de acolhimento e vínculo na perspectiva dos Agentes Comunitários de Saúde de um município da Região Noroeste do Rio Grande do Sul e sua utilização em ações de cuidado. Estudo de cunho qualitativo, desenvolvido com 11 participantes. Para a coleta de dados optou-se pela entrevista semiestruturada, e os dados foram analisados pela modalidade temática. O estudo revelou o acolhimento como atos e palavras receptivas e o vínculo como relação de amizade, confiança e compromisso. A utilização dessas tecnologias ocorreu, principalmente, na visita domiciliar, quando exercem a escuta ativa e disponibilizam orientações. Evidencia-se a necessidade de instrumentalizar os Agentes Comunitários e a equipe de saúde para ampliar a compreensão das tecnologias leves e reconhecer sua relevância no cuidado em saúde.

DESCRITORES: Saúde da família. Agente comunitário de saúde. Acolhimento.

\section{ACOGIMIENTO Y VÍNCULO EN LAS CONCEPCIONES Y PRÁCTICAS DE AGENTES COMUNITARIOS EN SALUD}

RESUMEN: Las tecnologías leves en salud facilitan la relación profesional/usuario, constituyéndose como importantes herramientas en el trabajo de los agentes comunitarios en salud que buscan conocer las dificultades de las familias y elaborar estrategias. El presente estudio objetivó conocer las nociones de acogimiento y vínculo en la perspectiva de los trabajadores comunitarios de salud de un municipio de la Región Norte de Rio Grande do Sul. Se caracteriza como un estudio con abordaje cualitativo, desarrollado con 11 participantes. Para la recolección de datos se optó por la entrevista semiestructurada, posteriormente fueron analizadas a través de la modalidad temática. El estudio demostró el acogimiento como actos y palabras receptivas y el vínculo como una relación de amistad, confianza y compromiso. La utilización de estas tecnologías ocurre, principalmente, en la visita domiciliar, durante la cual, se ejerce la escucha activa e información. Se evidencia la necesidad de instrumentalización de los agentes comunitarios de salud en el sentido de ampliar su comprensión sobre tecnologías leves, como también para reconocer su relevancia en el cuidado en salud.

DESCRIPTORES: Salud de la familia. Agentes comunitarios de salud. Acogimiento. 


\section{INTRODUCTION}

Health is a universal and fundamental right for human beings, guaranteed in the 1988 Federal Constitution and established in the Universal Declaration of Human Rights. ${ }^{1}$ Based on the theoretical and legal advances announced for the health area, health practices are centered on the development of social and economic policies that guarantee citizenship and democracy, besides reducing social inequalities. ${ }^{2}$

In the course of the consolidation of the Unified Health System (SUS), new strategies gradually emerged, motivated by the desire to apply the principles and guidelines of the SUS in their work practice. Therefore, the Ministry of Health (MH) invested in strategies that attended to the needs of the population, highlighting their priorities. Therefore, in 1991, the Community Health Agent Strategy (CHAS) was created, provoking a change in the current health model. To strengthen Primary Care, the objective of the CHAS is to support the organization of the SUS and comply with its principles and guidelines, mainly the decentralization of the health services and the complete attendance of the right to equality and social participation.

In that context, a new social actor emerges, the Community Health Agent (CHA). ${ }^{3}$ The CHA is part of the population and works through and for it. The main activities of this professional include the accompaniment of the families, individuals and groups to stimulate health promotion and the prevention of diseases and their problems. In addition, these professionals act in the family as mediators between the health system and the community, often permitting the solution of personal and family problems. ${ }^{2,4}$

The work and care process of the CHA's and the team is basically centered on the development of promotion and prevention activities, working with a broad health concept, mediating between the service and the community and among different forms of knowledge. Therefore, the health agents have health technologies at their disposal, specifically light technologies, and to develop these technologies in their daily work, they mainly depend on their knowledge and professional efforts, with a view to being successful and being able to interact with the users, identifying their needs and helping to attend to them.

Thus, the health technologies are fundamental tools for the CHAs' actions and are classified in three categories: hard technology, related to tech- nological equipment; light-hard technology, which comprises the knowledge in the health process; and light technology, which are the technologies of the relations, the communication, the welcoming, bonding and autonomy. ${ }^{5}$ The light technologies are used in the worker/user relation and permit the establishment of bonding, that is, acts that permit the production of relations between worker and user, expressing the construction or not of welcoming, bonding and accountability. ${ }^{6}$

In this study, only the light technologies welcoming and bonding were used, which aim to make the health actions more welcoming, agile and problem solving through the establishment of relations between workers and users. ${ }^{7}$ In addition, the welcoming and bonding actions can make the practices more effective and efficient through the construction of affective values and respect for other people's lives, allowing the traditional (curative and preventive) practices to gain a new dimension, based on the collective interest. ${ }^{8}$

Welcoming can be a strategy to restructure the curative and fragmented care model, making healthcare more welcoming and problem solving. In that sense, the health work process is modified by listening to the users and valuing their needs. ${ }^{9}$ It should be highlighted that, in this study, welcoming is more than just exercising qualified and interesting listening, it is a set of activities that involves listening, the identification of the problem and problem-solving intervention. ${ }^{10-11}$ Bonding, then, is a device that allows both the users and the workers to find their potential, establishing more reciprocal relations and permitting the construction of co-accountable and co-authored therapeutic acts. ${ }^{8}$ In this study, the bond is considered a nonimmediate conquest, as it might take some time to establish but, once consolidated, the stronger it is, the better the relation between professional and user will be, producing better results and enhancing the exchange of knowledge among the people involved. ${ }^{7}$

In view of the above, in this study, the goal was to get to know the concepts and practices of welcoming and bonding from the perspective of the Community Health Agents in the CHAS of a city in the Northwest of the State of Rio Grande do Sul.

\section{METHOD}

To achieve the proposed objective, a qualitative study was developed. The qualitative ap- 
proach permits unveiling social processes that are hardly known in particular groups, besides enhancing the creation of new approaches, the review and creation of new concepts and categories in the course of the investigation. ${ }^{12}$

The participants were 11 CHAs from the CHAS of a city located in the Northwest of the State of Rio Grande do Sul. The following criteria were used to select the participants: working at the moment of the data collection and being active for more than one year as a CHA.

The data were collected between July and August 2010 through a semistructured interview. To develop the interview, an instrument was constructed that consisted of two parts. The first included open and closed questions to collect the interviewees' sociodemographic data; in the second, open questions were asked on the CHAs' work process and the use of light technologies in health for the purpose of care production. The interviews were previously scheduled and held at an appropriate room, at the health unit the CHA was affiliated with, and recorded in mp4. To preserve the subjects' identity, in the statements, the abbreviation CHA was used, followed by an ordinal number to indicate the order of the interviews.

For the data analysis, thematic content analysis was used. ${ }^{12}$ Initially, the produced material was organized and the initial ideas were systemized. Then, the material was explored by coding, aiming for the classification and aggregation of the data, the transformation of the gross data to achieve the core understanding of the text. The final phase was the treatment and interpretation of the data. This phase evidenced the collected information, looking for inferences to facilitate other possibilities related to theoretical dimensions. The thematic axes that emerged from the analyses were: knowing the Community Health Agents' concepts of welcoming and bonding and the practice of welcoming and bonding in the CHAs' actions.

All ethical aspects of Resolution 196, issued on October $10^{\text {th }} 1996$, were considered, preserving the participants' secrecy and anonymity. In addition, all participants signed the Free and Informed Consent Form and received one copy, while the researcher filed another. Approval for the study was obtained from the Ethics Committee at Universidade Federal de Santa Maria, Process 23081.006580/2009-38.
PRESENTATION AND DISCUSSION OF THE RESULTS

\section{Discovering the concepts of welcoming and bonding according to the Community Health Agents}

The first thematic axis comprises the definition of welcoming and bonding in the CHAs' concepts. This axis permitted the construction of two sub-axes: Welcoming: welcoming and receiving; and Bonding: relation of friendship, trust and commitment.

In the first subaxis "welcoming: welcoming and receiving" it was identified that the CHAs mentioned the word welcoming, considering it as attitudes that demonstrate the good receptiveness, that is, the way the families receive them during home visits and vice-versa. That is clear in their statements:

I think it's the reception, the way you receive people, that must be it (CHA2).

welcoming is to treat well, welcoming, the word itself says it, I need to welcome, you see? Embrace, that's what comes to my mind, that's what I try to do (CHA9).

The findings support the data from the literature because, as regards the conception of welcoming, for the large majority of the interviewees, welcoming implies receiving the user well. ${ }^{13}$ Among the studies, one is highlighted whose objective was to characterize and analyze the work of the CHAs in family health teams. In this study, the authors identified a limited perspective of the health agent on welcoming and what the professionals who work at the reception of the health services should practice. ${ }^{14}$

In the concept of welcoming, their discourse also contained affectionate words like attention, kindness, love, and some mentioned the importance of knowing how to listen and identify the community's needs and demands. ${ }^{14}$ That is also clear in one participant's discourse:

welcoming is to understand the people, treat them well, dialogue with them [...] talk, pay attention to what they are saying, that's more or less it (CHA3).

The above statement reveals that welcoming went beyond receptiveness, as the CHA attempted to listen to the family's complaints. It is also observed, however, that the professionals faced difficulties to put that tool in practice because their mission is to listen and, what is more, to attend to all people's needs, which generates greater respon- 
sibility in their professional practice. ${ }^{15}$ Even when practicing active listening, welcoming remains fragmented, considering that its definition goes beyond attentive listening to something or somebody, as holistic welcoming means seeking positive answers and helping the family in its needs.

In that sense, it could be identified that the CHAs listened to the families' problems and, in most cases, faced difficulties to elaborate problemsolving strategies. This may be associated with the health services' structural difficulties and lack of enhanced understanding of the welcoming concept, summarizing this important tool in simple receptive words. Thus, the meaning of the word still does not cover the entire relation of identifying the problem and truly solving it. ${ }^{15}$ One study mentions that the CHAs work at the frontline of a system and often are not trained to attend to the countless demands that emerge in their daily work. In addition, there is the fact that they do not have exact definitions of their competences, skills and knowledge, living in a space of indeterminations and uncertainties. ${ }^{14}$

In the second subaxis "bonding: relation of friendship, trust and commitment", it could be identified that the health agents believe that bonding is relating to the other through bonds of friendship, in which the professional assumes a commitment to the community and the users establish a relation of trust with the worker to expose the difficulties they experience:

bonding? That you have affinity [...]. How should I say it, a commitment (CHA1).

bonding is when you are able to make a successful visit, that they really open up to you and manage to tell you what they are feeling (CHA6).

In a study undertaken to discover how the bond professional/user is established in the FHS teams, the interviewed subjects' perception of bonding was similar to what was identified in this study, reported as a relation between people (professional/user), developed in the community, and that aims for the user's trust in the professional. ${ }^{16}$

Bonding is a conquest and not an immediate event; it is a tool that permits the exchange of knowledge between the health worker and the community. Therefore, the more appropriate the bonding, the better its result will be. ${ }^{7}$

The bond can be understood as a relation of friendship, trust, accountability and commitment that is established with most families. The professionals aim to satisfy the basic needs the individuals manifest, furthering their quality of life. This reality was clear when the interviewees were asked about their relation with the users in the area they attend:

I think my relation in that community is good, because like, it's a very poor community, so I always attempt to attend to their needs, in accordance to what they ask (CHA2).

It's good, of friendship, of determination, trust and they show that they feel safe with me, to be able to talk about their problems (CHA6).

It was evidenced that the CHAs' insertion permits knowing the reality of the families' lives, making them feel responsible for that area and turn into reference persons. Thus, the agents work on behalf of the population, attempting to improve the health conditions, reflecting on the quality of life.

You even feel kind of responsible for the area you are working in [...] it's a matter of health and a social issue, you even have some influence in the community for you to help and I think it's through that bond that this happens (CHA10).

The co-accountability process of the $\mathrm{CHAs}$ was identified for the problems affecting the population's health, in the attempt to attend to the health needs that emerge in the context of each family, using the tools made available by the Family Health Unit. In some situations, the CHAs' possibilities for activities and problem solving can be limited, mainly as a part of the community they live and work in. ${ }^{14}$

It was observed that the CHAs know and understand the problems that affect the families under their responsibility. The notion of bonding, however, should not be summarized as knowing something or someone; it goes far beyond: the bond is a tool that permits the exchanges between the technical and the popular knowledge, the scientific and the empirical, the objective and the subjective, turning them into therapeutic actions fit for each group or individual. ${ }^{8}$

Some essential elements for bonding, evidenced in the discourse, have also been highlighted in other studies. In that sense, confidence, commitment, respect and empathy are essential with a view to greater knowledge of the community and, consequently, with a view to the establishment of bonding, improving the population's quality of life. ${ }^{16}$

Bonding is a tool that not only favors proximity and strengthens the professional relation 
between the health agent and the family, making the users feel more confident to report on the difficulties and risks they are exposed to, permitting comprehensive care. It is seen as a complex process and, in their concepts, the CHAs demonstrated some possibilities in that sense.

\section{The practice of welcoming and bonding in the Community Health Agents actions}

In this thematic axis, the CHAs' practice of welcoming and bonding in their daily work is discussed, identifying in what care actions these light technologies are present. Most of the health agents mentioned using it in their home visits, mainly when the family was going through some difficulty, when the professional needed to listen, provide orientations and inform in order to minimize the problems evidenced:

at home, when we arrive, for the sake of prevention, teaching, I think that it's the welcoming and this bond we have with them, this good contact, that we will be able to transmit correct information to them (CHA1).

The visit is a space of practical activity for the CHAs and challenges them to seek elements that favor their insertion in the family. The fact that the CHAs know their users and the priority of each is particularly based on the users' active listening, enhancing the bonding which, in turn, optimizes the care process. ${ }^{17}$

During the home visit, the CHA's most current activity, welcoming and bonding can be established and even strengthened, as it is one of the opportunities the professional has to construct a dialogue, knowing the family's needs and helping to solve the problems evidenced. Thus, it is during the home visits that the light technologies gain room for strengthening, as the relation between the users and health professionals is built in this dimension of listening and exchanges.

In view of the above, the home visit represents an important moment to establish relationship movements, besides encouraging the community and the families' independence for their own health production. In addition, the visit is established in loco, that is, at the place that represents the families and community's daily life, aiming to attend to the different health needs. ${ }^{18-19}$

Thus, the process of knowing how to listen attentively to the users' complaints allows them to feel important and favors the trust between user and professional, besides facilitating the establishment of bonding. ${ }^{16}$ The following statements reveal that most of the interviewees use welcoming and bonding for the families to receive them well, to establish a good relationship with the people and to develop the dialogue, in the attempt to identify not only health problems, but also intra-family problems:

[...] I use it a lot because, when you have a good relationship with the family, it makes it easier for us to work (CHA1).

[...] yes, because it's always like that, it's very important for you to have a bond with them, give them some time, listen to them, because you do not just go there to hear health and pain here pain there, you go there to hear even misunderstandings with the family, with the children (CHA6).

The care actions the health agents develop with the families are exactly what many people seek in the health services. The attentive look, involvement with the difficulties presented, listening, valuation of complaints and identification of needs are practical attitudes that surround the care process in health, whether in the individual or collective sphere. ${ }^{20}$

For the people who manifest attitudes of neediness and merely await the presence of someone who listens to them and offers them simple and significant words to relieve the anguish of living helplessly, perhaps knowing how to listen is enough. That is so because, in general, elderly people who live alone anxiously await the visit of the health agent who, with a simple gesture of listening, mitigates the suffering of their needs. This reality can be identified in the report below:

[...] I really like to work with elderly people, with children, family orientation, bedridden people [...]. The elderly are more needy, people who do no longer walk, had problems, who were confined inside a house, hardly went out, I think they are the ones who most need and most like visits like that (CHA7).

In these situations, what is most important is to know that there are people who identify this need and dedicate some of their time to it, as this act enriches their work and values their profession. In the health agents' work, sometimes, listening is more important than arriving at the home and offering information that is not suitable to that reality or will be useless at that time. Therefore, it is important for the CHA to use welcoming and bonding in all daily work activities to take not only educational-preventive actions to the families/ community/individuals, but also listening and dialogue. 
Daily contact with the community, that is, the fact that the CHAs live in the activity area, also strengthens the establishment of welcoming and bonding, because they know all people by their name, identifying them and the family they belong to, making the population feel more at ease and develop more confidence, forwarding their health problems to solve them. ${ }^{17}$ In addition, living in the activity area allows the CHAs good knowledge about the problems that affect the subjects, families and community, many of which even go beyond the professional's technical ability to solve. ${ }^{21}$

Thus, the health agents' use of light technologies revealed their skills and sensitivity to deal with all situations, which go far beyond the health problems. Thus, the interpersonal relationship between the health workers and user/family needs to be considered as a whole, ranging from the physical to the emotional condition, in which besides their technical and scientific knowledge, the professionals promote acts of solidarity and understanding, putting in practice their relational technologies, being accountable for the other and mainly for humanized care. ${ }^{20}$

Among the activities the CHAs develop, the activity that best permits the practical construction and strengthening of the light technologies is the home visit, as this care action allows the professionals to frequently circulate in the "world" the family lives in, facilitating the contact with the people and permitting welcoming and bonding. Therefore, once again, the importance of the light technologies is highlighted, especially welcoming and bonding in health. It was evidenced that they are present in the CHAs' work in many forms and approaches and deserve to be further elaborated and discussed by the health teams.

\section{FINAL CONSIDERATIONS}

This study permitted knowledge about the CHAs' concepts of the technologies welcoming and bonding and in what daily actions these technologies are used. The CHAs understand welcoming as receptive and affectionate actions and words. Bonding, on the other hand, is understood as a relation of trust, commitment and friendship. The use of these tools in their daily actions prevails during home visits, which favor the identification of health and intra-family problems through active listening and dialogue.

In this study, it could be identified that welcoming and bonding are being used in the $\mathrm{CHAs}^{\prime}$ health practices, but often in a fragmented manner.
The professionals were able to inter-relate with the attended families, mainly through dialogue. This process permitted the identification of some of the problems the families experience, but this conduct is expected to go beyond the identification, achieving the problem solving of the users' needs.

It is highlighted that the study was accomplished in a given reality and context, which may not represent generalization of the data, but shows important elements to consider strategies and actions in the CHAs' work process that can be enhanced with a view to humanized and comprehensive healthcare.

The study showed the need to value the CHAs' capacity, for example, in the community life plan that needs to be respected and valued. Furthermore, it was demonstrated that their contribution, at collective moments, as a team, can produce knowledge and actions that are selfsupportive, to the benefit of truly welcoming and problem-solving care, perhaps consolidating the ability the create new ethical practices, committed to the users' rights to citizenship. In that sense, the creation of collective spaces for discussion is suggested in the health teams and the construction of care actions that get mobilized to attend to the community's demands, considering the relational technologies as tools that drive comprehensive care, in a perspective that puts forward the users as subjects in health production.

\section{REFERÊNCIAS}

1. Ministério da Saúde (BR). Secretaria Executiva, Departamento de apoio à descentralização esplanada dos ministérios. OSUS no seu município garantindo saúde para todos. Brasília (DF): MS; 2004.

2. Simões AR. O agente comunitário de saúde na equipe de saúde da família: fatores de sobrecarga de trabalho e estresse. Rev Saúde Pública. 2009; 2(1):6-21.

3. BornStein VJ, David HMSL, AraújoJWG. Community health agents: reconstruction of the risk concept at local level. Interface - Comunic Saude Educ. 2010; 14(32):93-101.

4. Binda J, Bianco MF, Sousa EM. O trabalho dos agentes comunitários de saúde em evidência: uma análise com foco na atividade. Saúde Soc. 2013; 22(2):389-402.

5. Silva DC, Alvim NAT, Figueiredo PA. Tecnologias leves em saúde e sua relação com o cuidado de enfermagem hospitalar. In: Merhy EE, Onocko, R. Práxis em salud um desafio para lo público. São Paulo (SP): Hucitec; 1997.

6. Merhy EE. Um ensaio sobre o médico e suas valises tecnológicas: contribuições para compreender 
as reestruturações produtivas do setor da saúde. Interface Comunic Saúde Educ. 2000 Fev; (6):109-16.

7. Coelho MO, Jorge MSB. Tecnologias das relações como dispositivo do atendimento humanizado na atenção básica a saúde na perspectiva do acesso, do acolhimento e do vínculo. Ciênc Saúde Coletiva. 2009; 14(1):1523-31.

8. Santos AM, Assis MMA, Nascimento MAA, Jorge MSB. Vínculo e autonomia na prática de saúde bucal no Programa Saúde da Família. Rev Saúde Pública. 2008 Jun; 42(3):464-70.

9. Guerrero P, Mello ALZF, Andrade SR, Erdmann AL. User embracement as a good practice in primary health care. Texto Contexto-Enferm. 2013 Jan-Mar; 22(1):132-40.

10. Arruda C, Silva DMGV. Acolhimento e vínculo na humanização do cuidado de enfermagem às pessoas com Diabetes Mellitus. Rev Bras Enferm. 2012; 65(5):758-66.

11. Jorge MSB, Pinto DM, Quinderé HD, Pinto AGA, Sousa FSP, Cavalcante CM. Promoção da saúde mental - tecnologias do cuidado: vínculo, acolhimento, co-responsabilização e autonomia. Ciência Saúde Coletiva. 2011; 16(7):3051-60.

12. Minayo MCS. O desafio do conhecimento: pesquisa qualitativa em saúde. $11^{\text {a }}$ ed. São Paulo (SP): Hucitec; 2010.

13. Mitre SM, Andrade EIG, Cotta RMM. Avanços e desafios do acolhimento na operacionalização e qualificação do Sistema Único de Saúde na atenção primária: um resgate da produção bibliográfica do Brasil. Ciência Saúde Coletiva. 2012; 17(8):2071-85.
14. Galavote HS, Prado TN, Maciel ELN, Lima RCD. Desvendando os processos de trabalho do agente comunitário de saúde nos cenários revelados na Estratégia Saúde da Família no município de Vitória. Ciênc Saúde Coletiva. 2011; 16(1):231-40.

15. Takemoto MLS, Silva EM. Acolhimento e transformações no processo de trabalho de enfermagem em unidades básicas de saúde de Campinas, São Paulo, Brasil. Cad Saúde Pública. 2007; 23(2):331-40.

16. Monteiro MM, Figueiredo VP, Machado MFAS. Formação do vínculo na implantação do Programa Saúde da Família numa unidade básica de saúde. Rev Esc Enferm USP. 2009 Jun; 43(2):358-64.

17. Guedes MVC, Henriques ACPT, Lima MMN. Acolhimento em um serviço de emergência: percepção dos usuários. Rev Bras Enferm. 2013; 66(1):31-7.

18. Lopes WO, Saupe R, Massaroli A. Visita domiciliar: tecnologia para o cuidado, o ensino e a pesquisa. Cienc Cuid Saúde. 2008 Abr-Jun; 7(2):241-7.

19. Torres HC, Roque C, Nunes C. Visita domiciliar: estratégia educativa para o autocuidado de clientes diabéticos na atenção básica. Rev Enferm UERJ. 2011; 19(1):89-93.

20. Schneider DG, Manschein AMM, Ausen MAB, Martins JJ, Albuquerque GL. Acolhimento ao paciente e família na unidade coronariana. Texto Contexto Enferm. 2008; 17(1):81-9.

21. Peres CRFB, Caldas Júnior AL, Silva RF, Marin MJS. The community health agent and working as a team: the easy and difficult aspects. Rev Esc Enferm USP. 2011; 45(4):899-905. 